\title{
Pemanfaatan Kompos Jerami Padi dan Biochar Sekam Padi Untuk Memperbaiki Sifat Kimia Tanah dan Meningkatkan Produksi Padi Lokal di Kecamatan Teupah Barat Kabupaten Simeulue
}

\author{
(Utilization of Rice Straw Compost and Rice Husk biochar to Improve Soil Chemical \\ Properties and Increase Local Rice Production in West Teupah Barat Subdistrict \\ Simeulue)
}

\author{
Omi Wahyuni Kasari ${ }^{1}$, Munawar Khalil ${ }^{1}$, Yadi Jufri ${ }^{1 *}$ \\ ${ }^{1}$ Program Studi Ilmu Tanah, Fakultas Pertanian, Universitas Syiah Kuala \\ *Corresponding author: yadijufri65@gmail.com
}

\begin{abstract}
Abstrak. Tanaman padi (Oryza sativa L.) merupakan tanaman pangan utama dan komoditi strategis bagi Indoesia. Produksi padi nasional belum mampu mencukupi kebutuhan penduduk banyak, kebijakan yang dilakukan seperti penggunaan varietas unggul, pembangunan sarana irigasi, subsidi benih, pupuk, dan penggunaan pestisida dalam meningkatkan produksi padi secara nasional. Salah satu hal terpenting dalam meningkatkan produksi padi yaitu dengan menyediakan pupuk organik (Kompos Jerami dan Biochar Sekam Padi) dan pupuk anorganik (Urea, SP36 dan $\mathrm{KCl}$ ) dengan berbagai dosis sehingga dapat memberikan pengaruh terhadap padi lokal Varietas Babulon dan memperbaiki sifat kimia tanah. Beberapa permasalahan yang sering ditemukan pada lahan sawah Kecamatan Teupah Barat Kabupaten Simeulue di antaranya C-organik sangat rendah, N-total sangat rendah dan P-total sangat rendah. Oleh karena itu, pengelolaan lahan sawah di Kecamatan Teupah Barat Kabupaten Simeulue perlu diperhatikan. Penelitian ini menggunakan Rancangan Acak Kelompok (RAK) Non- Faktorial yang terdiri dari 8 perlakuan dan 3 ulangan. Parameter sifat kimia tanah yang diamati adalah C-organik, N-total, P-total, P-tersedia, $\mathrm{K}$-dd dan $\mathrm{pH} \mathrm{H}_{2} \mathrm{O}$ sedangkan parameter pertumbuhan padi lokal Varietas Babulon adalah tinggi tanaman, jumlah anakan, berat berangkasan basah, berat berangkasan kering, dan berat gabah per rumpun. Pemberian pupuk organik (Kompos Jerami dan Biochar Sekam Padi)) dan pupuk anorganik dapat memperbaiki sifat kimia tanah serta meningkatkan hasil peroduksi padi dari biasanya. Produksi padi lokal meningkat menjadi 6,45 dari 3,4 ton/ha dengan pemberian pupuk kompos 20 ton/ha, biochar sekam padi 5 ton/ha, urea $200 \mathrm{~kg} / \mathrm{ha}$, SP-36 $200 \mathrm{~kg} / \mathrm{ha} \mathrm{dan}$ $\mathrm{KCl} 150 \mathrm{~kg} / \mathrm{ha}$ (perlakuan F).
\end{abstract}

Kata Kunci: Pemanfaatan, kompos, biochar, sifat kimia tana, produksi padi lokal

\begin{abstract}
Abstrac. Rice plants (Oryaa ana L) are the main pungan crop and a strategic commodity for Indocsia Namonal rice production has not been sufficient needs of the population at large, policies implemented are like the use of superior varieties. weep pnasad veeunluad unp ynd yruag prsyna selun mues uunlunqund ujep Huyuadan ne yres euorseu JEDeS ped ypoad urpylura increases rice production by separating organic fertilizers (Kempos Straw and Biochar Rice Husk) and various inorganic fertilizers (Urea, SP-36 and $\mathrm{KCl}$ ) so that it can have an effect on local rice Vanetas Babulon and improve soil chemistry. Some of the problems that are often found in the sub-area of Teupah Rarat sub-district, Simeulue.Regency include very low Carganik, very low N-atal and very low P-al. rice fields in Teupah Baran Subdistrict, Simeulue Regency, need to be observed. This research used a Non-factorial Randomized Design (RAK) which consisted of treatment and 3 replications. K-dd and $\mathrm{pH} \mathrm{H}_{2} \mathrm{O}$, meanwhile the puramrter growth of lakal rice Vanetas Babulon is crop seed, number of tillers, herat hasah acid, dry weight, and gahah weight per clump. Provision of organic fertilizers (Straw Compost and Biochar Sckan Rice) and inorganic fertilizers can improve the chemical properties and increase the pudi's yield of the hives. Local rice products frame 645 from 3,4 ionh with giving 20 nha of camphor fertilizer, 3 tonnes of bochar rice husk, 200 kgha urea. SP-36 $200 \mathrm{~kg}$ ha and $\mathrm{Ka} 150 \mathrm{kgha}$ (treatment F)
\end{abstract}

Keywords: utilization, compost, biochar, soil chamical properties, lokal rice production

\section{PENDAHULUAN}

Padi (Oryza sativa L.) merupakan bahan pangan utama dan komoditi strategi bagi Indonesia. Pada kenyataannya produksi padi nasional belum mampu mencukupi kebutuhan penduduk dengan banyaknya kebijakan yang dilakukan seperti penggunaan varietas unggul, 
pembangunan sarana irigasi, subsidi benih, pupuk, dan penggunaan pestisida dalam meningkatkan produksi padi secara nasional (Kartasapoetro, 1988).

Kompos adalah salah satu pupuk organik buatan manusia yang dibuat dari proses pembusukan sisa-sisa bahan organik seperti tanaman maupun hewan. Proses pengomposan dapat berlangsung secara aerobik yaitu melibatkan oksigen dan anaerobik atau tanpa menggunakan oksigen di dalam prosesnya. Proses dekomposisi atau penguraian inilah menjadikannya sebagai pupuk kompos. Proses pengomposan adalah proses dimana bahan organik mengalami penguraian secara biologis, khususnya oleh mikroba-mikroba yang memanfaatkan bahan organik sebagai sumber energi. (Nuraini, 2009).

Jerami padi merupakan bahan organik potensial yang paling banyak dimiliki oleh petani padi. Sebagai sumber bahan organik tanah, pemberian jerami padi dapat dibedakan menjadi tiga macam, 1). pemberian jerami padi dalam bentuk brangkasan kering, 2). pemberian jerami dalam bentuk abu dan 3). pemberian dalam bentuk kompos jerami. Hardiatmi (2006) telah melakukan kajian yang bertujuan untuk mengetahui bentuk pemberian jerami serta dosis jerami yang paling tepat terhadap serapan hara tanaman. Hasilnya yaitu pemberian jerami dalam bentuk kompos memberikan pengaruh terbaik terhadap serapan hara $\mathrm{N}$ dan $\mathrm{K}$, diikuti bentuk brangkasan kering kemudian terendah adalah bentuk abu (Soeryoko, 2011).

Biochar merupakan materi padat yang terbentuk dari karbonisasi biomasa. Biochar dapat ditambahkan ke tanah untuk meningkatkan fungsi tanah dan mengurangi emisi dari biomasa yang secara alami terurai menjadi gas rumah kaca. Biochar berguna sebagai pembenah tanah yang penting pada tanah yang miskin hara, kekurangan bahan organik, kekurangan air dan ketersediaan pupuk kimia. Biochar juga meningkatkan kualitas dan kuantitas air dengan meningkatnya penyimpanan tanah bagi unsur hara dan agrokimia yang digunakan oleh tanaman (IBI, 2012).

Kecamatan Teupah Barat merupakan bagian dari Kabupaten Simeulue yang mana sebagian besar masyarakatnya sebagai petani membudidayakan tanaman padi. Varietas padi yang umum mereka gunakan oleh petani adalah padi varietas lokal dan varietas unggul. Petani di daerah ini lebih sering menggunakan padi varietas lokal dari pada padi varietas unggul. Produksi padi sawah dapat dikatakan masih tergolong rendah. Pada umumnya rata-rata hasil produksi padi sawah varietas lokal di Kecamatan Teupah Barat sekitar 3,2 ton/ha. Lahan sawah di Kecamatan Teupah Barat pada umumnya adalah lahan sawah tadah hujan, hanya sebagian kecil lahan sawah irigasi. Salah satu masalah yang menyebabkan hasil produksi padi rendah di daerah ini adalah petani tidak melakukan pemupukan pada tanaman padi mereka.

Penelitian ini bertujuan untuk mengetahui pengaruh pemberian limbah panen padi berupa kompos jerami padi dan biochar sekam padi sebagai bahan pembenah tanah terhadap perubahan sifat kimia dan produksi tanaman padi lokal.

\section{METODE PENELITIAN}

Penelitian ini dilaksanakan di Desa Leubang Kecamatan Teupah Barat Kabupaten Simeulue. Penelitian berlangsung selama 4 bulan dimulai dari bulan Agustus sampai dengan Desember 2019.

Alat yang digunakan dalam penelitian ini adalah cangkul, sekop, ayakan, papan plat, perlakuan, ember, timbangan, oven, dan alat-alat di laboratorium. Bahan yang digunakan dalam penelitian ini adalah benih padi varietas lokal (Babulon), pupuk organik dan anogranik. Pupuk organik yang digunakan adalah kompos jerami padi dan biochar sekam padi dan pupuk anorganik yaitu pupuk Urea dengan dosis $200 \mathrm{~kg} / \mathrm{ha}$, SP-36 dengan dosis $200 \mathrm{~kg} / \mathrm{ha}$ dan $\mathrm{KCl}$ dengan dosis $150 \mathrm{~kg} / \mathrm{ha}$ (Rekomendasi dari BPP) Kecamatan Teupah Barat. 
Penelitian ini menggunakan metode Rancangan Acak Kelompok Non-faktorial dengan 8 perlakuan dan 3 ulangan. Setiap perlakuan dibuat 3 kali, sehingga jumlah keseluruhannya adalah 72 ember. Adapun dosis perlakuan A : (kontrol), B : (1,5 g/ember Urea + 1,5 g/ember $\mathrm{SP} 36+1,125 \mathrm{~g} / \mathrm{ember} \mathrm{KCl}+0$ g/ember Kompos dan 0 g/emeber Biochar), $\mathrm{C}:(1,5 \mathrm{~g} / \mathrm{ember}$ $\mathrm{Urea}+1,5 \mathrm{~g} / \mathrm{ember} \mathrm{SP} 36+1,125 \mathrm{~g} / \mathrm{ember} \mathrm{KCl}+37,5 \mathrm{~g} / \mathrm{ember} \mathrm{Kompos}$ dan 0 g/emeber Biochar), D : (1,5 g/ember Urea + 1,5 g/ember SP36 + 1,125 g/ember $\mathrm{KCl}+37,5 \mathrm{~g} / \mathrm{ember}$ Kompos dan 3,75 g/emeber Biochar), E : (1,5 g/ember Urea + 1,5 g/ember SP36 + 1,125 $\mathrm{g} /$ ember $\mathrm{KCl}+75 \mathrm{~g} / \mathrm{ember}$ Kompos dan 3,75 g/emeber Biochar), $\mathrm{F}:(1,5 \mathrm{~g} / \mathrm{ember}$ Urea + 1,5 g/ember SP36 + 1,125 g/ember $\mathrm{KCl}+150$ g/ember Kompos dan 3,75 g/emeber Biochar), $\mathrm{G}$ : $(1,5 \mathrm{~g} / \mathrm{ember} U$ rea $+1,5 \mathrm{~g} / \mathrm{ember} \mathrm{SP} 36+1,125 \mathrm{~g} / \mathrm{ember} \mathrm{KCl}+225 \mathrm{~g} / \mathrm{ember}$ Kompos dan 3,75 g/emeber Biochar) dan $\mathrm{H}:(1,5 \mathrm{~g} / \mathrm{ember}$ Urea $+1,5 \mathrm{~g} / \mathrm{ember} \mathrm{SP} 36+1,125 \mathrm{~g} / \mathrm{ember} \mathrm{KCl}+225$ g/ember Kompos dan 150 g/emeber Biochar).

\section{Pelaksanaan Penelitian Persiapan Media Tanam}

Permukaan tanah dibersihkan dari kotoran rumput, akar atau batu kemudian tanah di ambil sedalam 0-20 $\mathrm{cm}$ sesuai kebutuhan, tanah yang telah diambil dikering anginkan selama 2 hari dan kemudian ditumbuk sampai halus guna untuk mempermudah pelumpuran, tanah yang telah selesai ditumbuk ditimbang sebanyak $15 \mathrm{~kg}$, tanah yang telah ditimbang dimasukan ke dalam ember ukuran $20 \mathrm{~kg}$ kemudian ditambahkan pupuk organik yaitu kompos jerami dan biochar sekam padi untuk diinkubasi selama 14 hari, inkubasi, dalam kondisi macak-macak dilakukan selama 1 minggu sebelum tanam.

\section{Persiapan Bahan Dan Persemaian}

Disiapkan benih padi (Babulon) yang telah diseleksi dengan cara memilih benih yang bernas. Pemilihan benih ini dilakukan untuk menghindari resiko kegagalan dalam penelitian akibat benih yang rusak, benih yang telah disiapkan kemudian direndam dengan air yang bersih selama 12 jam, dan kemudian ditiriskan selama lebih kurang 30 menit. Setelah ditiriskan benih dibungkus dengan kain dan didiamkan selama 2 hari sampai benih tumbuh tunas, benih yang telah tumbuh tunas kemudian ditaburkan di tempat persemaian padi yang telah disiapkan dan diletakan di dalam keranjang yang dilapisi dengan kertas, persemaian benih dilakukan selama 10-12 hari sehingga benih siap dipindahkan ketempat penanaman.

\section{Pemupukan}

Pemupukan dilakukan setelah tanah dilumpurkan dan pemberian pupuk organik (Kompos dan Biochar) diberikan sebelum dilumpurkan, dan diinkubasi selama 2 minggu sebelum penanaman, sedangkan pupuk anorganik (Urea, SP-36, $\mathrm{KCl}$ ) diberikan pada saat penanaman sesuai dengan dosis perlakuan. Pemupukan urea akan dilakukan dua kali yaitu pada saat tanam dan 3 minggu setelah tanam. Untuk sekali pemberian sebanyak 0,75 g/ember.

\section{Penanaman}

Penanaman diilakukan setelah bibit padi berumur 12 hari setelah semai, dengan ciri-ciri bibit telah memiliki dua helai atau tiga helai daun. Penanaman dilakukan dengan cara memindahkan bibit padi ke dalam ember yang telah disiapkan. Bibit padi ditanam sebanyak 3 batang/pot 


\section{Pemeliharaan}

Pemeliharaan yang dilakukan yaitu berupa penyiangan gulma, penyulaman dan pengendalian hama dan penyakit. Penyiangan dilakukan selama 3 minggu sekali atau tergantung pertumbuhan gulma, sedangkan penyulaman pada saat tanaman padi berumur 7 hari setelah tanam (HST) dan pengendalian hama dilakukan pada saat hama dan penyakit telah mengganggu tanaman padi.

\section{Pemanenan}

Pemanenan dilakukan apabila gabah telah menguning, isi gabah telah keras dan tanaman padi sudah mulai tampak mengerin.

\section{Parameter Penelitian}

\section{Analisis Sifat Kimia Tanah}

Analisis sifat kimia tanah dilakukan dua kali yaitu analisi tanah awal atau sebelum perlakuan dan analisis tanah setelah diberikan perlakuan. Adapun parameter yang dianalisis sebelum dan sesudah perlakuan $\mathrm{pH}_{2} \mathrm{O}$, C- Organik, $\mathrm{N}$ - total, dan $\mathrm{P}$ - tersedia.

Adapun parameter pengamatan pertumbuhan tanaman padi yaitu Tinggi Tanaman (umur 15, 30, 45, 60, 75, dan 90 HST) dan Jumlah Anakan (Umur 30 dan 60 HST), dan parameter pengamatan untuk produksi tanaman padi yaitu Berat Berangkasan Basah (Pada Saat Panen), Berat Berangkasan Kering (10 Hari Setelah Panen) dan Berat Gabah/Rumpun (Pada Saat Panen 122 hari).

\section{Pengolahan Data}

Untuk mengetahui pengaruh perlakuan terhadap variabel yang diamati, maka data yang diperoleh dalam penelitian ini dianalisis secara statistik menggunakan analis sidik ragam, dan jika terdapat perbedaan nyata atau sangat nyata antar perlakuan akan dilanjutkan dengan uji BNJ.

\section{HASIL DAN PEMBAHASAN}

\section{Analisis Sifat Kimia Tanah}

\section{Hasil Analisis Tanah Awal}

Hasil analisis tanah sawah dengan pemberian limbah panen padi yang dilakukan di Labolatorium Kimia Tanah Fakultas Pertanian Universitas Syiah Kuala dan Balai Pengkajian Teknologi Pertanian (BPTP) Aceh pada Desa Leubang Kecamatan Teupah Barat Kabupaten Simeulue disajikan pada Tabel 1.

Tabel 1. Hasil Analisis Tanah Awal

\begin{tabular}{llll}
\hline No & Analisis Sifat Kimia Tanah & Nilai & Karakteristik \\
1 & pH $\mathrm{H}_{2} \mathrm{O}$ & 5,52 & Masam \\
2 & C-Organik $(\%)$ & 0,55 & Rendah \\
3 & N-Total $(\%)$ & 0,30 & Rendah \\
4 & P-Tersedia (ppm) & 115,36 & Sangat Tinggi \\
\hline
\end{tabular}

Sumber: Laboratorium Kimia Tanah Fakultas Pertanian

Tabel 1 menunjukkan bahwa sifat kimia sampel tanah awal atau sebelum perlakuan memiki $\mathrm{pH} \mathrm{H}_{2} \mathrm{O}$ masam, C-organik rendah, $\mathrm{N}$-total rendah, $\mathrm{P}$-tersedia sangat tinggi dan 
Rendahnya hara di dalam tanah terjadi karena mininnya dilakukan pemupukan pada lahan sawah sehingga hara tidak tersedia untuk tanaman. C-organik tergolong rendah terjadi karena kurangnya penambahan bahan organik yang di berikan ke dalam tanah Sejalan dengan penelitian Gani (2009), menyatakan bahwa pemberian Biochar pada tanah dapat meningkatkan C-organik dalam tanah.

\section{Analisis Tanah Setelah Perlakuan Hasil Analisis pH Tanah}

Berdasarkan hasil analisis sidik ragam $\mathrm{pH}$ menunjukan bahwa pemberian limbah panen padi dan pupuk anorganik berpengaruh nyata terhadap $\mathrm{pH}$ tanah. Rata-rata $\mathrm{pH}$ tanah akibat pemberian limbah panen padi dan pupuk anorganik dapat dilihat pada Tabel 2.

Tabel 2. Rata-rata Kandungan Rata-rata pH Tanah

\begin{tabular}{|c|c|c|c|c|c|c|c|}
\hline \multirow[t]{2}{*}{ Kode Perlakuan } & \multicolumn{5}{|c|}{ Perlakuan } & \multirow[t]{2}{*}{$\begin{array}{l}\text { Nilai } \\
\text { tanah }\end{array}$} & \multirow[t]{2}{*}{ Rata-rata $\mathrm{pH}$} \\
\hline & $\begin{array}{l}\text { Urea } \\
\text { (kg/ha) }\end{array}$ & $\begin{array}{l}\text { SP-36 } \\
\text { (kg/ha) }\end{array}$ & $\begin{array}{l}\mathrm{KCl} \\
\text { (kg/ha) }\end{array}$ & $\begin{array}{l}\text { Kompos } \\
\text { (ton/ha) }\end{array}$ & $\begin{array}{l}\text { Biochar } \\
\text { (ton/ha) }\end{array}$ & & \\
\hline $\mathrm{A}$ & 200 & 200 & 150 & 0 & 0 & & $6,12 \mathrm{a}$ \\
\hline $\mathrm{B}$ & 200 & 200 & 150 & 0 & 0 & & $6,12 \mathrm{a}$ \\
\hline $\mathrm{C}$ & 200 & 200 & 150 & 5 & 0 & & $6,16 b$ \\
\hline $\mathrm{D}$ & 200 & 200 & 150 & 5 & 5 & & $6,20 \mathrm{c}$ \\
\hline $\mathrm{E}$ & 200 & 200 & 150 & 10 & 5 & & $6,20 \mathrm{c}$ \\
\hline $\mathrm{F}$ & 200 & 200 & 150 & 20 & 5 & & $6,21 \mathrm{c}$ \\
\hline $\mathrm{G}$ & 200 & 200 & 150 & 30 & 5 & & $6,26 \mathrm{~d}$ \\
\hline $\mathrm{H}$ & 200 & 200 & 150 & 30 & 20 & & $6,25 \mathrm{~d}$ \\
\hline
\end{tabular}

Keterangan: Angka yang diikuti huruf yang sama pada kolom yang sama tidak berbeda nyata pada uji lanjut BNJ 0,05

Tabel 2 menunjukan bahwa rata-rata $\mathrm{pH}$ tanah akibat dari pemberian limbah panen padi dan pupuk anorganik berkisar antara 6,12 sampai 6,26. Dari hasil penelitian yang telah dilakukan pada lahan sawah di Desa Leubang Kecamatan Teupah Barat Kabupaten Simeulue berpengaruh nyata meningkatkan $\mathrm{pH}$ tanah. Hal ini terjadi karena pelepasan asam-asam organik, pemberian kompos jerami pada tanah yang bersifat masam dapat meningkatkan $\mathrm{pH}$ tanah, karena dekomposisi yang membentuk humus dapat meningkatkan hidrogen. Sesuai dengan pernyataan Atmojo (2003) pemberian bahan organik pada tanah masam ( $\mathrm{pH}$ rendah) hidrogen akan terikat pada gugus aktifnya yang menyebabkan gugus aktif berubah menjadi bermuatan positif.

\section{Analisis C-Organik}

Berdasarkan hasil analisis sidik ragam C-organik menunjukan bahwa pemberian limbah panen padi dan pupuk anorganik berpengaruh sangat nyata terhadap C-organik tanah. Rata-rata C-organik tanah akibat pemberian limbah panen padi dan pupuk anorganik dapat dilihat pada Tabel 3.

Tabel 3 menunjukkan bahwa nilai rata-rata C-organik tanah dari pemberian kompos jerami padi, biochar sekam padi dan pupuk anorganik berkisar antara 1,38\% sampai 1,82\%. Dari hasil penelitian yang telah dilakukan pada lahan sawah di Desa Leubang Kecamatan Teupah Barat Kabupaten Simeulue berpengaruh sangat nyata meningkatkan C-organik tanah. Peningkatan $\mathrm{C}$-organik juga dipengaruhi oleh rasio $\mathrm{C} / \mathrm{N}$ kompos jerami tersebut. Menurut 
Steiner (2007) menyatakan bahwa penambahan kompos jerami dan biochar ke dalam tanah dapat memperkaya C-organik tanah.

Tabel 3. Hasil Rata-rata C-organik Tanah (\%).

\begin{tabular}{|c|c|c|c|c|c|c|}
\hline \multirow[t]{2}{*}{$\begin{array}{l}\text { Kode } \\
\text { Perlakuan }\end{array}$} & \multicolumn{5}{|c|}{ Perlakuan } & \multirow[t]{2}{*}{$\begin{array}{l}\text { Nilai Rata-rata C-organik } \\
\operatorname{tanah}(\%)\end{array}$} \\
\hline & $\begin{array}{l}\text { Urea } \\
(\mathrm{kg} / \mathrm{ha})\end{array}$ & $\begin{array}{l}\text { SP-36 } \\
\text { (kg/ha) }\end{array}$ & $\begin{array}{l}\mathrm{KCl} \\
\text { (kg/ha) }\end{array}$ & $\begin{array}{l}\text { Kompos } \\
\text { (ton/ha) }\end{array}$ & $\begin{array}{l}\text { Biochar } \\
\text { (ton/ha) }\end{array}$ & \\
\hline $\mathrm{A}$ & 200 & 200 & 150 & 0 & 0 & $1,38 \mathrm{a}$ \\
\hline B & 200 & 200 & 150 & 0 & 0 & $1,41 \mathrm{a}$ \\
\hline $\mathrm{C}$ & 200 & 200 & 150 & 5 & 0 & $1,38 \mathrm{a}$ \\
\hline $\mathrm{D}$ & 200 & 200 & 150 & 5 & 5 & $1,79 a$ \\
\hline $\mathrm{E}$ & 200 & 200 & 150 & 10 & 5 & $1,82 \mathrm{a}$ \\
\hline $\mathrm{F}$ & 200 & 200 & 150 & 20 & 5 & $1,28 \mathrm{a}$ \\
\hline $\mathrm{G}$ & 200 & 200 & 150 & 30 & 5 & $1,58 \mathrm{a}$ \\
\hline $\mathrm{H}$ & 200 & 200 & 150 & 30 & 20 & $1,79 a$ \\
\hline
\end{tabular}

Keterangan: Angka yang diikuti huruf yang sama pada kolom yang sama tidak berbeda nyata pada uji lanjut BNJ 0,05

\section{Analisis N-total}

Hasil analisis sidik ragam $\mathrm{N}$-total tanah menunjukan bahwa pemberian limbah panen padi dan pupuk anorganik berpengaruh tidak nyata terhadap N-total tanah. Rata-rata N-total tanah akibat pemberian limbah panen padi dan pupuk anorganik dapat dilihat pada Tabel 4.

Tabel 4. Rata-rata Kandungan N-total Tanah (\%)

\begin{tabular}{ccccccc}
\hline Kode Perlakuan & \multicolumn{7}{c}{ Perlakuan } & Nilai N-total Tanah \\
& \multicolumn{7}{c}{$\begin{array}{c}\text { Krea } \\
\text { (kg/ha) }\end{array}$} & $\begin{array}{l}\text { SP-36 } \\
(\mathrm{kg} / \mathrm{ha})\end{array}$ & $\begin{array}{l}\mathrm{KCl} \\
(\mathrm{kg} / \mathrm{ha})\end{array}$ & $\begin{array}{l}\text { Kompos } \\
\text { (ton/ha) }\end{array}$ & $\begin{array}{c}\text { Biochar } \\
(\text { ton/ha })\end{array}$ & \\
\hline A & 200 & 200 & 150 & 0 & 0 & 0,10 \\
B & 200 & 200 & 150 & 0 & 0 & 1,13 \\
C & 200 & 200 & 150 & 5 & 0 & 0,11 \\
D & 200 & 200 & 150 & 5 & 5 & 0,10 \\
E & 200 & 200 & 150 & 10 & 5 & 0,13 \\
F & 200 & 200 & 150 & 20 & 5 & 0,10 \\
G & 200 & 200 & 150 & 30 & 5 & 0,09 \\
H & 200 & 200 & 150 & 30 & 20 & \\
\hline
\end{tabular}

Tabel 4 menunjukan bahwa nilai rata-rata $\mathrm{N}$-total tanah melalui pemberian limbah panen padi dan pupuk anorganik berkisar antara 0,09\% sampai 0,14\%. Dari hasil penelitian yang telah dilakukan pada lahan sawah di Desa Leubang Kecamatan Teupah Barat Kabupaten Simeulue tidak terjadi peningkatan. Hal ini karena unsur hara $\mathrm{N}$ sudah dipakai tanaman tanaman selama 50 hari pertumbuhan vegetatif. Penelitian Muhammad (2013) menyatakan bahwa kombinasi kompos biochar dan pupuk anorganik dapat meningkatkan unsur nitrogen di dalam tanah dan berfungsi memacu pertumbuhan tanaman. 


\section{Analisis P-tersedia}

Hasil analisis sidik ragam P-tersedia menunjukan bahwa pemberian limbah panen padi dan pupuk anorganik tidak berpengaruh nyata terhadap P-tersedia. Rata-rata P-tersedia tanah akibat pemberian limbah panen padi dan pupuk anorganik dapat dilihat pada Tabel 5.

Tabel 5. Rata-rata Kandungan P-tersedia Tanah (ppm)

\begin{tabular}{|c|c|c|c|c|c|c|c|}
\hline \multirow[t]{2}{*}{ Kode Perlakuan } & \multicolumn{5}{|c|}{ Perlakuan } & \multirow[t]{2}{*}{$\begin{array}{l}\text { Nilai } \\
\text { tanah }\end{array}$} & \multirow[t]{2}{*}{ Rata-rata $\mathrm{pH}$} \\
\hline & $\begin{array}{l}\text { Urea } \\
(\mathrm{kg} / \mathrm{ha})\end{array}$ & $\begin{array}{l}\text { SP-36 } \\
\text { (kg/ha) }\end{array}$ & $\begin{array}{l}\mathrm{KCl} \\
(\mathrm{kg} / \mathrm{ha})\end{array}$ & $\begin{array}{l}\text { Kompos } \\
\text { (ton/ha) }\end{array}$ & $\begin{array}{l}\text { Biochar } \\
\text { (ton/ha) }\end{array}$ & & \\
\hline $\mathrm{A}$ & 200 & 200 & 150 & 0 & 0 & & $6,12 \mathrm{a}$ \\
\hline B & 200 & 200 & 150 & 0 & 0 & & $6,12 \mathrm{a}$ \\
\hline $\mathrm{C}$ & 200 & 200 & 150 & 5 & 0 & & $6,16 b$ \\
\hline D & 200 & 200 & 150 & 5 & 5 & & $6,20 \mathrm{c}$ \\
\hline $\mathrm{E}$ & 200 & 200 & 150 & 10 & 5 & & $6,20 \mathrm{c}$ \\
\hline $\mathrm{F}$ & 200 & 200 & 150 & 20 & 5 & & $6,21 c$ \\
\hline $\mathrm{G}$ & 200 & 200 & 150 & 30 & 5 & & $6,26 \mathrm{~d}$ \\
\hline $\mathrm{H}$ & 200 & 200 & 150 & 30 & 20 & & $6,25 \mathrm{~d}$ \\
\hline
\end{tabular}

Uji Lanjut BNJ 0,05

0,02

Keterangan: Angka yang diikuti huruf yang sama pada kolom yang sama tidak berbeda nyata pada uji lanjut BNJ 0,05

Tabel 5 menunjukan bahwa rata-rata P-tersedia tanah akibat pemberian limbah panen padi dan pupuk anorganik berkisar antara 68,20 sampai 129,19 pmm. Dari hasil penelitian yang telah dilakukan pada lahan sawah di Desa Leubang Kecamata Teupah Barat Kabupaten Simeulue pada data statistik tidak berpengaruh nyata, sedangkan di lapangan terjadi peningkatan. Ketersediaan unsur hara $\mathrm{P}$ dalam tanah dapat mempercepat pertumbuhan anakan dan pembentukan biji. Sejalan dengan penelitian Mukhlis et.al., (2011) meyatakan bahwa penambahan bahan organik ke dalam tanah mampu meningkatkan P-tersedia karena dapat membentuk ikatan kompleks dengan $\mathrm{Al}$ sehingga mengurangi retensi $\mathrm{P}$ oleh $\mathrm{Al}$ dan $\mathrm{Fe}$.

\section{Pertumbuhan Tanaman}

\section{Pengukuran Tinggi Tanaman}

Hasil analisis sidik ragam menunjukkan bahwa pemberian limbah panen padi dan pupuk anorganik pada tinggi tanaman 15 HST berpengaruh nyata, pada tinggi tanaman 30 HST tidak berpengaruh nyata dan pada tinggi tanaman 45 HST berpengaruh sangat nyata. Rata-rata tinggi tanaman dari pemberian limbah panen padi dan pupuk anorganik dapat dilihat pada Tabel 6.

Tabel 6 menunjukan bahwa rata-rata tinggi tanaman akibat pemberian limbah panen padi dan pupuk anorganik berpengaruh nyata pada tinggi tanaman 15 HST sedangkan pada tinggi tanaman 30 HST tidak berpengaruh nyata dan berpengaruh sangat nyata pada tinggi tanaman 45 HST. Pemberian limbah panen padi dan pupuk anorganik berpengaruh nyata terhadap tinggi tanaman padi pada umur 15 HST yaitu $34,89 \mathrm{~cm}$. Menurut Aribawa (2012) menyatakan bahwa tanaman yang tumbuh dengan baik mampu menyerap unsur hara dalam jumlah banyak, ketersedian hara dalam tanah berpengaruh terhadap aktivitas tanaman.

Pemberian limbah panen padi dan pupuk anorganik tidak berpengaruh nyata terhadap tinggi tanaman padi pada umur 30 HST. Sejalan dengan penelitian Sikuku et al. (2015) menyatakan bahwa perbedaan tinggi tanaman berpengaruh dari perbedaan dosis pupuk yang digunakan pada setiap perlakuan.

Pemberian limbah panen padi dan pupuk anorganik berpengaruh sangat nyata terhadap tinggi tanaman umur 45 HST yaitu $87,89 \mathrm{~cm}$. Selain meningkatkan tinggi tanaman pemberian 
limbah panen padi dan pupuk organik yang juga dapat meningkatkan unsur hara di dalam tanah, terutama unsur hara makro yang sangat dibutuhkan tanaman untuk pertumbuhan. Sejalan dengan penelitian Adiningsih (1992) menyatakan bahwa pemupukan dan penambahan bahan organik sangat respon terhadap pertumbuhan tanaman padi.

Tabel 6. Hasil Pengukuran Tinggi Tanaman Akibat Kombinasi Pemupukan organik dan anorganik 15, 30, dan 45 HST

\begin{tabular}{|c|c|c|c|c|c|c|c|c|c|}
\hline \multirow[t]{2}{*}{ No } & \multirow[t]{2}{*}{ Kode } & \multirow{2}{*}{$\begin{array}{c}\text { Dosis } \\
\text { Urea } \\
\mathrm{kg} / \mathrm{ha} \\
\end{array}$} & \multirow{2}{*}{$\begin{array}{l}\text { Dosis } \\
\text { SP36 } \\
\mathrm{kg} / \mathrm{ha} \\
\end{array}$} & \multirow{2}{*}{$\begin{array}{c}\text { Dosis } \\
\mathrm{KCl} \\
\mathrm{kg} / \mathrm{ha} \\
\end{array}$} & \multirow{2}{*}{$\begin{array}{c}\text { Dosis } \\
\text { Kompos } \\
\text { ton/ha }\end{array}$} & \multirow{2}{*}{$\begin{array}{c}\text { Dosis } \\
\text { Biochar } \\
\text { ton/ha }\end{array}$} & \multicolumn{3}{|c|}{$\begin{array}{c}\text { Rata-rata Tinggi Tanaman Padi } \\
\text { Umur }(\mathrm{cm})\end{array}$} \\
\hline & & & & & & & $15 \mathrm{HTS}$ & $30 \mathrm{HTS}$ & $45 \mathrm{HTS}$ \\
\hline 1 & A & 0 & 0 & 0 & 0 & 0 & $25,97 a$ & 47,03 & $68,78 \mathrm{a}$ \\
\hline 2 & B & 200 & 200 & 150 & 0 & 0 & $27,14 \mathrm{ab}$ & 50,16 & $69,34 \mathrm{a}$ \\
\hline 3 & $\mathrm{C}$ & 200 & 200 & 150 & 5 & 0 & $30,14 \mathrm{ab}$ & 51,28 & $69,86 a$ \\
\hline 4 & D & 200 & 200 & 150 & 5 & 5 & $29,44 \mathrm{ab}$ & 49,91 & $79,60 \mathrm{c}$ \\
\hline 5 & $\mathrm{E}$ & 200 & 200 & 150 & 10 & 5 & $31,40 \mathrm{ab}$ & 53,20 & $70,67 \mathrm{ab}$ \\
\hline 6 & $\mathrm{~F}$ & 200 & 200 & 150 & 20 & 5 & $31,41 \mathrm{ab}$ & 54,10 & $73,04 \mathrm{abc}$ \\
\hline 7 & $\mathrm{G}$ & 200 & 200 & 150 & 30 & 5 & $34,89 b$ & 57,12 & 74,77abc \\
\hline 8 & $\mathrm{H}$ & 200 & 200 & 150 & 30 & 20 & $33,37 b$ & 57,00 & $87,89 d$ \\
\hline
\end{tabular}

$$
\text { Uji Lanjut BNJ } 00,5
$$

6,72

7,46

Keterangan: Angka yang diikuti huruf yang sama pada kolom yang sama tidak berbeda nyata pada uji lanjut BNJ 0,05

Berdasarkan hasil analisis sidik ragam menunjukan bahwa pemberian limbah panen padi dan pupuk anorganik tidak berpengaruh nyata terhadap tinggi tanaman 60, 75, dan 90 HST. Rata-rata tinggi tanaman akibat pemberian limbah panen dan pupuk anoganik dapat dilihat pada Tabel 7.

Tabel 7. Hasil Pengukuran Tinggi Tanaman Akibat Kombinasi Pemupukan organik dan anorganik 60, 75, dan 90 HST

\begin{tabular}{cccccccccc}
\hline No & Kode & $\begin{array}{c}\text { Dosis } \\
\text { Urea }\end{array}$ & $\begin{array}{c}\text { Dosis } \\
\text { SP36 }\end{array}$ & $\begin{array}{c}\text { Dosis } \\
\mathrm{KCl}\end{array}$ & $\begin{array}{c}\text { Dosis } \\
\text { Kompos }\end{array}$ & $\begin{array}{c}\text { Dosis } \\
\text { Biochar }\end{array}$ & \multicolumn{2}{c}{$\begin{array}{c}\text { Rata-rata Tinggi Tanaman Padi } \\
\text { Umur }(\mathrm{cm})\end{array}$} \\
\hline & & $\mathrm{kg} / \mathrm{ha}$ & $\mathrm{kg} / \mathrm{ha}$ & $\mathrm{kg} / \mathrm{ha}$ & ton/ha & ton/ha & $60 \mathrm{HTS}$ & $75 \mathrm{HTS}$ & $95 \mathrm{HTS}$ \\
\hline 1 & $\mathrm{~A}$ & 0 & 0 & 0 & 0 & 0 & 83,78 & 96,16 & 101,36 \\
2 & $\mathrm{~B}$ & 200 & 200 & 150 & 0 & 0 & 84,22 & 95,32 & 101,53 \\
3 & $\mathrm{C}$ & 200 & 200 & 150 & 5 & 0 & 86,03 & 98,53 & 101,89 \\
4 & $\mathrm{D}$ & 200 & 200 & 150 & 5 & 5 & 92,99 & 107,31 & 108,42 \\
5 & $\mathrm{E}$ & 200 & 200 & 150 & 10 & 5 & 85,67 & 97,27 & 109,93 \\
6 & $\mathrm{~F}$ & 200 & 200 & 150 & 20 & 5 & 87,82 & 98,18 & 101,06 \\
7 & $\mathrm{G}$ & 200 & 200 & 150 & 30 & 5 & 91,80 & 102,57 & 105,37 \\
8 & $\mathrm{H}$ & 200 & 200 & 150 & 30 & 20 & 104,41 & 116,06 & 105,82
\end{tabular}

Tabel 7 menunjukan bahwa rata-rata tinggi tanaman akibat pemberian limbah panen padi dan pupuk anorganik pada tinggi tanaman 60,75 dan 90 HST pada data statistik berpengaruh tidak nyata, sedangkan di lapangan mengalami peningkatan terhadap tinggi tanaman padi. Pemberian limbah panen padi dan pupuk anorganik berpengaruh tidak nyata terhadap tinggi tanaman padi pada umur 60 HST yaitu $104,41 \mathrm{~cm}$.

Pada umur 70 HST beberapa batang tanaman padi sudah terlihat bulat dan pada umur 82 HTS semua batang sudah bulat atau bunting, tanaman padi pertama kali mulai terlihat keluar malai yaitu pada umur 87 HTS. 
Pemberian limbah panen padi dan pupuk anorganik berpengaruh tidak nyata terhadap tinggi tanaman umur 75 HST namun angka tertinggi yaitu $116,06 \mathrm{~cm}$. Sejalan dengan penelitian Suprihatno (2010) meyatakan bahwa tinggi rendahnya batang tanaman dipengaruhi sifat atau ciri varietas tanaman padi yang ditanam. Pemberian limbah panen padi dan pupuk anorganik berpengaruh tidak nyata terhadap tinggi tanaman umur 90 HST namun angka tertinggi yaitu $109,93 \mathrm{~cm}$.

Tanaman padi varietas lokal (Babulon) pada umur 87 HST beberapa tanaman mulai keluar malai. Pada umur 90 HST sebagian besar malai padi sudah keluar hanya sebagian kecil yang belum keluar malai yaitu pada anakan padi yang lebih kecil. Tanaman padi pertama kali mulai muncul bunga pada malai yaitu pada umur 94 HST. Pada setiap malai padi mulai terjadi masak susu setelah proses keluarnya bunga yaitu sekitar umur 100 HST. Malai tanaman padi mulai terlihat menguning yaitu sekitar umur 110 HST namun sebagian besar malai tanaman masih ada yang terlihat berwarna hijau. Pada umur 120 HST telah terlihat malai sudah menguning semua dan panen dilakukan pada umur 122 HST.

\section{Jumlah Anakan Tanaman Padi}

Berdasarkan hasil analisis sidik ragam menunjukan bahwa pemberian limbah panen padi dan pupuk anorganik berpengaruh nyata terhadap jumlah anakan tanaman padi pada umur 30 dan 60 HST. Rata-rata jumlah anakan padi akibat pemberian limbah panen padi dan pupuk anorganik dapat dilihat pada Tabel 8.

Tabel 8. Hasil Perthitungan Jumlah Anakan Tanaman Padi Akibat Dari Kombinasi Pupuk Anorganik, Pupuk Kompos dan Biochar Pada Umur 30 HST dan 60 HST

\begin{tabular}{ccccccccc}
\hline No & Kode & $\begin{array}{c}\text { Dosis } \\
\text { Urea }\end{array}$ & $\begin{array}{c}\text { Dosis } \\
\text { SP36 }\end{array}$ & $\begin{array}{c}\text { Dosis } \\
\text { KCl }\end{array}$ & $\begin{array}{c}\text { Dosis } \\
\text { Kompos }\end{array}$ & $\begin{array}{c}\text { Dosis } \\
\text { Biochar }\end{array}$ & \multicolumn{2}{c}{$\begin{array}{c}\text { Rata-rata Jumlah Anakan } \\
\text { Tanaman }\end{array}$} \\
\hline & & $\mathrm{kg} / \mathrm{ha}$ & $\mathrm{kg} / \mathrm{ha}$ & $\mathrm{kg} / \mathrm{ha}$ & ton/ha & ton/ha & 30 HST & $40 \mathrm{HST}$ \\
\hline 1 & $\mathrm{~A}$ & 0 & 0 & 0 & 0 & 0 & $9 \mathrm{a}$ & $13 \mathrm{a}$ \\
2 & $\mathrm{~B}$ & 200 & 200 & 150 & 0 & 0 & $17 \mathrm{~b}$ & $20 \mathrm{a}$ \\
3 & $\mathrm{C}$ & 200 & 200 & 150 & 5 & 0 & $16 \mathrm{ab}$ & $20 \mathrm{a}$ \\
4 & $\mathrm{D}$ & 200 & 200 & 150 & 5 & 5 & $15 \mathrm{ab}$ & $20 \mathrm{a}$ \\
5 & $\mathrm{E}$ & 200 & 200 & 150 & 10 & 5 & $16 \mathrm{ab}$ & $20 \mathrm{a}$ \\
6 & $\mathrm{~F}$ & 200 & 200 & 150 & 20 & 5 & $20 \mathrm{~b}$ & $24 \mathrm{~b}$ \\
7 & $\mathrm{G}$ & 200 & 200 & 150 & 30 & 5 & $17 \mathrm{~b}$ & $22 \mathrm{~b}$ \\
8 & $\mathrm{H}$ & 200 & 200 & 150 & 30 & 20 & $19 \mathrm{~b}$ & $23 \mathrm{~b}$ \\
\hline
\end{tabular}

Keterangan: Angka yang diikuti huruf yang sama pada kolom yang sama tidak berbeda nyata pada uji lanjut BNJ 0,05

Tabel 8 menunjukan bahwa rata-rata jumlah anakan akibat pemberian limbah panen padi dan pupuk anorganik berpengaruh nyata pada umur 30 dan 60 HST. Akibat pemberian limbah panen padi dan pupuk anorganik berpengaruh nyata terhadap jumlah anakan $30 \mathrm{HST}$ yaitu 20 batang pada perlakuan F. Hal ini terjadi karena unsur hara di dalam tanah cukup tersedia untuk tanaman sehingga dapat meningkatkan jumlah anakan tanaman. Lakitan (2008) 
menyatakan bahwa jumlah unsur hara yang dibutuhkan tanaman berkaitan dengan kebutuhan tanaman untuk dapat tumbuh dengan baik, ditambahkan Husna (2010) menyatakan bahwa jumlah anakan maksimal dipengaruhi faktor genetik dan lingkungan.

Pemberian limbah panen padi dan pupuk anorganik berpengaruh nyata terhadap jumlah anakan 60 HST dengan jumlah tertinggi yaitu 24 batang pada perlakuan F. Hal ini terjadi karena peningkatan jumlah anakan tanaman padi dipengaruhi oleh ketersediaan unsur hara di dalam tanah. AAK (1990) menyatakan bahwa jumlah anakan maksimum dicapai pada umur 50-60 HST, kemudian anakan yang terbentuk setelah mencapai batas maksimum akan berkurang karena pertumbuhanya yang lemah bahkan mati. Ditambah Abdullah et al., (2006) menyatakan bahwa anakan utama juga cenderung menghasilkan gabah yang lebih tinggi dari anakan kedua, ketiga dan seterusnya.

\section{Berat Berangkasan Basah dan Berangkasan Kering}

Hasil analisis sidik ragam menunjukan bahwa pemberian limbah panen padi dan pupuk anorganik berpengaruh nyata terhadap berat berangkasan basah dan berangkasan kering. Ratarata berat berangkasan basah dan berangkasan kering dapat dilihat pada Tabel 9.

Tabel 9. Hasil Perhitungan Berat Berangkasan Basah dan Berat Berangkasan Kering Akibat Kombnasi Pupuk Anorganik, Pupuk Kompos dan Biochar.

\begin{tabular}{ccccccccc}
\hline No & Kode & $\begin{array}{c}\text { Dosis } \\
\text { Urea }\end{array}$ & $\begin{array}{c}\text { Dosis } \\
\mathrm{SP36}\end{array}$ & $\begin{array}{c}\text { Dosis } \\
\mathrm{KCl}\end{array}$ & $\begin{array}{c}\text { Dosis } \\
\text { Kompos }\end{array}$ & $\begin{array}{c}\text { Dosis } \\
\text { Biochar }\end{array}$ & \multicolumn{2}{c}{$\begin{array}{c}\text { Rata-rata Berat Brangkasan } \\
(\mathrm{gr})\end{array}$} \\
\hline & & $\mathrm{kg} / \mathrm{ha}$ & $\mathrm{kg} / \mathrm{ha}$ & $\mathrm{kg} / \mathrm{ha}$ & ton/ha & ton/ha & $\begin{array}{c}\text { Brangkasan } \\
\text { Basah }\end{array}$ & $\begin{array}{c}\text { Brangkasan } \\
\text { Kering }\end{array}$ \\
\hline 1 & $\mathrm{~A}$ & 0 & 0 & 0 & 0 & 0 & $10,07 \mathrm{a}$ & $6,99 \mathrm{a}$ \\
2 & $\mathrm{~B}$ & 200 & 200 & 150 & 0 & 0 & $17,72 \mathrm{~b}$ & $14,23 \mathrm{~b}$ \\
3 & $\mathrm{C}$ & 200 & 200 & 150 & 5 & 0 & $19,80 \mathrm{~b}$ & $16,22 \mathrm{~b}$ \\
4 & $\mathrm{D}$ & 200 & 200 & 150 & 5 & 5 & $21,13 \mathrm{~b}$ & $18,08 \mathrm{~b}$ \\
5 & $\mathrm{E}$ & 200 & 200 & 150 & 10 & 5 & $21,29 \mathrm{~b}$ & $17,84 \mathrm{~b}$ \\
6 & $\mathrm{~F}$ & 200 & 200 & 150 & 20 & 5 & $30,28 \mathrm{c}$ & $26,60 \mathrm{c}$ \\
7 & $\mathrm{G}$ & 200 & 200 & 150 & 30 & 5 & $23,57 \mathrm{~b}$ & $20,18 \mathrm{~b}$ \\
8 & $\mathrm{H}$ & 200 & 200 & 150 & 30 & 20 & $23,48 \mathrm{~b}$ & $19,98 \mathrm{~b}$ \\
\hline
\end{tabular}

Keterangan: Angka yang diikuti huruf yang sama pada kolom yang sama tidak berbeda nyata pada uji lanjut BNJ 0,05

Tabel 9 menunjukan bahwa pemberian limbah panen padi dan pupuk anorganik berpengaruh nyata terhadap berat berangkasan basah dan berat berangkasan kering tanaman padi. Pemberian limbah panen padi dan pupuk anorganik berpengaruh nyata terhadap berat berangkasan basah dengan nilai tertinggi yaitu 30,28 g. Hal ini terjadi karena berat berangkasan basah berkaitan dengan tinggi tanamanan jumlah anakan dipengaruhi oleh kandungan air. Menurut Dwijoseputro (1992) menyatakan bahwa tanaman yang mempunyai pertumbuhan yang baik akan mengandung hampir $90 \%$ air pada jaringannya.

Pemberian limbah panen padi dan pupuk anorganik berpengaruh nyata terhadap berat berangkasan kering tanaman padi dengan nilai tertinggi yaitu 26,60 g. Hal ini terjadi karena 
berat berangkasan kering dipengaruhi oleh lamanya dilakukan kering angin tanaman. Semakin lama dilakukan kering angin maka semakin rendah pula berat berangkasan kering. Berat berangkasan kering juga dipengaruhi oleh unsur hara yang diserap oleh tanaman pada saat pertumbuhan vegetatif. Sejalan dengan peneitian Yurnavila (2015) menyatakan bahwa pemberian pupuk NPK dapat pertumbuhan vegetatif tanaman padi.

\section{Hasil Produksi Padi}

Berdasarkan hasil analisis sidik ragam menunjukan bahwa pemberian limbah panen padi dan pupuk anorganik berpengaruh nyata terhadap hasil produksi padi. Rata-rata hasil produksi padi dapat dilihat pada Tabel 10.

Tabel 10. Hasil Perhitungan Berat Gabah/Rumpun Tanaman Padi Akibat Kombnasi Pupuk Anorganik, Pupuk Kompos dan Biochar.

\begin{tabular}{|c|c|c|c|c|c|c|c|c|}
\hline No & Kode & $\begin{array}{l}\text { Dosis } \\
\text { Urea }\end{array}$ & $\begin{array}{l}\text { Dosis } \\
\text { SP36 }\end{array}$ & $\begin{array}{c}\text { Dosis } \\
\mathrm{KCl}\end{array}$ & $\begin{array}{l}\text { Dosis } \\
\text { Kompos }\end{array}$ & $\begin{array}{c}\text { Dosis } \\
\text { Biochar }\end{array}$ & $\begin{array}{c}\text { Rata-rata Berat } \\
\text { Gabah/Rumpun (g) }\end{array}$ & $\begin{array}{l}\text { Produksi/ha } \\
\text { (kg/ha) }\end{array}$ \\
\hline & & $\mathrm{kg} / \mathrm{ha}$ & $\mathrm{kg} / \mathrm{ha}$ & $\mathrm{kg} / \mathrm{ha}$ & ton/ha & ton/ha & Berat Gabah/Rumpun & \\
\hline 1 & A & 0 & 0 & 0 & 0 & 0 & $6,43 a$ & $1608,33 a$ \\
\hline 2 & B & 200 & 200 & 150 & 0 & 0 & $13,08 b$ & $3450,83 \mathrm{ab}$ \\
\hline 3 & $\mathrm{C}$ & 200 & 200 & 150 & 5 & 0 & $15,36 \mathrm{bc}$ & $3840,27 \mathrm{ab}$ \\
\hline 4 & D & 200 & 200 & 150 & 5 & 5 & $17,13 b c$ & $4283,61 \mathrm{ab}$ \\
\hline 5 & E & 200 & 200 & 150 & 10 & 5 & $17,27 b c$ & $4317,77 \mathrm{ab}$ \\
\hline 6 & F & 200 & 200 & 150 & 20 & 5 & $25,83 \mathrm{~d}$ & $6456,66 \mathrm{~b}$ \\
\hline 7 & G & 200 & 200 & 150 & 30 & 5 & $19,12 b c$ & $4781.11 \mathrm{ab}$ \\
\hline 8 & $\mathrm{H}$ & 200 & 200 & 150 & 30 & 20 & $20,04 \mathrm{~cd}$ & $5010,55 \mathrm{ab}$ \\
\hline
\end{tabular}

Keterangan: Angka yang diikuti huruf yang sama pada kolom yang sama tidak berbeda nyata pada uji lanjut BNJ 0,05

Tabel 10 menunjukan bahwa pemberian limbah panen padi dan pupuk anorganik berpengaruh nyata terhadap hasil produksi tanaman padi. Pemberian limbah panen padi dan pupuk anorganik berpengaruh nyata terhadap produksi tanaman padi sawah dengan nilai tertinggi yaitu $25,83 \mathrm{~g}$. Adapun hasil produksi padi $\mathrm{kg} / \mathrm{ha}$ pemberian limbah panen padi dan pupuk anorganik berpengaruh nyata terhadap produksi tanaman padi sawah yaitu 6456,66 $\mathrm{kg} / \mathrm{ha}$. Pemupukan yang diberikan pada lahan sawah selain dapat meningkatkan unsur P dari belum tersedia menjadi tersedia. Dengan meningkatnya unsur hara P-tersedia tanah, hasil produksi padi juga mengalami penigkatan karena salah satu unsur hara yang memacu pembentukan biji padi adalah unsur hara P. Sejalan dengan penelitian Nazarudi et al., (2010) menyatakan bahwa pengaplikasian kompos jerami mampu mensuplai kebutuhan tanamaman untuk meningkatkan produksi. 


\section{KESIMPULAN DAN SARAN}

\section{Kesimpulan}

Dari hasil penelitian yang telah dilakukan dapat disimpulkan sebagai berikut:

1. Pemberian kompos jerami padi, biochar sekam padi dan pupuk anorganik ke dalam tanah mampu meningkatkan ketersedian unsur hara $\mathrm{P}$ yang dibutuhkan oleh tanaman.

2. Pemberian kompos jerami padi, biochar sekam padi dan pupuk anorganik mampu meningkatkan pertumbuhan dan hasil produksi padi sawah dari sebelumnya yaitu 3,4 ton/ha menjadi 6,45 ton/ha

3. Produksi padi tertinggi diperoleh dengan kombinasi pemberian $200 \mathrm{~kg} / \mathrm{ha}$ urea, 200 $\mathrm{kg} / \mathrm{ha} \mathrm{SP} 36$ dan $150 \mathrm{~kg} / \mathrm{ha} \mathrm{KCl}$ dengan 20 ton/ha kompos jerami dan 5 ton/ha biochar sekam padi.

\section{Saran}

1. Untuk dapat merekomendasikan dosis pemupukan tersebut perlu dilakukan percobaan sekali lagi dengan pembuatan demplot (demontasi plot) percobaan di lapangan menggunakan dosis terbaik diatas, dan sebaiknya limbah sisa panen padi dimanfaatkan sebagai kompos jerami dan biochar sekam padi.

2. Untuk menigkatkan pertumbuhan dan hasil produksi padi yang lebih baik perlu dilakukan penambahan pupuk kompos jerami dengan dosis 20 ton/ha dan biochar sekam padi dengan dosis 5 ton/ha.

\section{DAFTAR PUSTAKA}

AAK, 1990. Budidaya Tanaman Padi. Penerbit Kanisus, Yogyakarta.

Adiningsih, J.S. 1992. Peran Efisiensi Penggunaan Pupuk Untuk Melestarikan Swasembada Pangan. Orasi Pengukuran Ahli Penelitian Utama. Jakarta.

Aribawa. 2012. Pengaruh Sistem Tanam terhadap Peningkatan Produktivitas Padi di Lahan

Sawah Dataran Tinggi Beriklim Basah. Balai Pengkajian Teknologi Pertanian (BPTP) Bali.

Dwidjoseputro, D. 1992. Pengantar Fisioogi Tumbuhan. Jakarta. Gramedia.

Gani, A. 2009. Potensi Arang Hayati Biochar Sebagai Komponen Teknologi Perbaikan Produktivitas Lahan Pertanian. Iptek Tanaman Pangan.

Husna, Y. 2010. Pengaruh Penggunaan Jarak Tanam Terhadap Pertumbuhan dan Produksi padi. Kartasapoetro, A.G. 1988. Teknologi Budidaya Tanaman Pangan di Daerah Tropika. Binaaksara, Jakarta.

Lakitan, B. 2008. Dasar- Dasar fisiologi Tumbuhan. Raja Gravindo Persada. Jakarta

Muhammad. 2013. Pengaruh Berbagai Pembenah Tanah Terhadap Pertumbuhan dan Pupulasi Tanaman Padi Sawah. Agrotek Indonesia.

Mukhlis, Sarifuddin, dan Hanum. 2011. Kimia Tanah. USU Press, Medan.

Nazarudin, T. Nurmala dan T. Simarmata. 2010. Pertumbuhan dan Hasil Tanaman Padi Akibat Pemberian Kompos Jerami dan Pupuk Kalium Pada Sistem Teknologi Intensifikasi Aerob Terkendali Berbasis Organik di Aceh Utara. Thesis Program Pasca Sarjana. Unpad. Bandung.

Nuaraini. 2009. Pembuatan Kompos Jerami Menggunakan Mikroba Perombak Bahan Organik. Buletin Teknik Pertanian. 
Yurnavira, I. 2015. Pengaruh Jenis Pupuk Organik dan Dosis pupuk NPK Terhadap Pertumbuhan dan Hail Padi Sawah Pada Sistem Konvensiona. Fakulas Pertanian Universitas Tamansiswa Padang 